\title{
Temporary neurologic complication of spinal ropivacaine in an obstetric patient
}

\author{
Obstetrik hastada spinal ropivakainin geçici nörolojik komplikasyonu
}

\author{
다 Nurten KAYACAN, (D) Bilge KARSLI
}

\begin{abstract}
Summary
We aimed to inform transient neurological symptoms after spinal anesthesia and to review postpartum neurological deficits of regional anesthesia. A previously healthy 25 -year-old primigravid woman underwent an elective cesarean section. Hypotension and bradycardia were not observed during the operation. On the $25^{\text {th }}$ day postpartum, the patient suffered from numbness and weakness at the lower extremity. On neurological assessment, the muscle strengths in the gastrocnemius and quadriceps bilaterally were $2 / 5(+)$ and $3 / 5(+)$, respectively. The muscle strength at foot dorsiflexion and plantar flexion were $2 / 5(+)$ bilaterally. The patient was unable to walk on toes and walked on heels, and the lower extremities were hypoesthetic. The patellar and the Achilles tendon reflexes were bilaterally negative. No pathological findings could be detected on lumbosacral magnetic resonance imaging (MRI). Electromyography revealed a mixed type of polyneuropathy. The symptoms relieved partially at the end of the $2^{\text {nd }}$ month and regressed completely at the end of the $3^{\text {rd }}$ month. To prevention of irreversible postpartum permanent neurologic deficits, the diagnosis should be made using a detailed neurologic examination along with MRI or computed tomography.
\end{abstract}

Keywords: Local anaesthetics; neuropathy; neurotoxicity; spinal anaesthesia; transient neurological symptom.

\begin{abstract}
Özet
Spinal anestezi sonrası geçici nörolojik semptomları bildirmeyi ve bölgesel anestezinin postpartum nörolojik sorunlarını gözden geçirmeyi amaçladık. 25 yaşında, sağlıklı primigravid bir kadına elektif sezaryen uygulandı. Ameliyat sırasında hipotansiyon ve bradikardi görülmedi. Sezaryenden sonraki 25. günde hasta, alt ekstremitede hissizlik ve halsizlik bildirdi. Nörolojik değerlendirmede, bilateral olarak gastrokinemius ve kuadriseps kas gücü sırasıyla $2 / 5(+)$ ve $3 / 5(+)$ idi. Ayak dorsifleksiyonu ve plantar fleksiyondaki kas gücü $2 / 2(+)$ bilateral idi. Hasta ayak parmakları üzerinde yürüyemedi, topuklar üzerinde yürüdü ve alt ekstremiteler hipoestezikti. Patellar ve aşil tendonu refleksleri bilateral olarak negatiftir. Lumbosakral MRG'de patolojik bulgu saptanamamıştır. EMG'de karışık tipte bir polinöropati görüldü. Semptomlar kısmen ikinci ayın sonunda hafiflemiş ve üçüncü ayın sonunda tamamen gerilemiştir.

Sonuç olarak, doğum sonu geri dönüşümsüz, kalıcı nörolojik defisitlerin önlenmesi için, MRG veya BT ile birlikte yapılan nörolojik muayene ile tanı konulmalıdır.

Anahtar sözcükler: Lokal anestezikler; nöropati; nörotoksisiste; spinal anestezi; geçici nörolojik semptom.
\end{abstract}

\section{Introduction}

Central neuraxial block (CNB) is one of the most common methods of anesthesia in obstetric anesthesia. ${ }^{[1]}$ Fortunately, serious neurological complications related to regional anesthesia are very rare. ${ }^{[2]}$

Ropivacaine is a new long-acting amino-amide local anesthetic with differential sensory-motor block, had been widely used in obstetric patients. ${ }^{[3,4]} \mathrm{Com}$ pared with bupivacaine, ropivacaine had less cardiac and central nerve system toxicity, less motor blocking properties, and earlier mobilization. ${ }^{[5]}$

Due to the temporal relationship with CNB, the anesthetist is often the first physician notified when a woman reports postpartum neurological symptoms. Anesthetists must be able to differentiate between the causes of neurological injury and recognize the rare injury that requires immediate intervention to avoid permanent disability. ${ }^{[6]}$ 
In this case report, we aimed to inform transient neurological symptoms after spinal anesthesia in a patient underwent cesarean section and to review postpartum neurological deficits of regional anesthesia.

\section{Case Report}

A previously healthy 25 -years-old primigravid woman with a 40-week gestation underwent an elective cesarean section. There was no contraindication for spinal anesthesia. The patient underwent standard monitoring, including continuous electrocardiogram, pulse oximetry, and non-invasive measurement of arterial blood pressure. Pre-anesthetic arterial blood pressure was $125 / 75 \mathrm{mmHg}$ and the heart rate was $80 \mathrm{bpm}$. Intravenous access was secured in the non-dominant forearm, and an IV preload of 20 $\mathrm{mL} / \mathrm{kg}$ of Ringer's Lactate solution was administered prior to spinal anesthesia. The patient was placed in the left lateral decubitis position, and a 25-gauge Whitacre needle was inserted into the L3-4 intervertebral space. After confirming free flow of cerebrospinal fluid, ropivacaine $15 \mathrm{mg}$ was administered over approximately $60 \mathrm{~s}$. During placement of the spinal needle and injection of drug, there was no pain, paresthesia, bleeding, or difficulty. Surgery was permitted to commence when the upper dermatomal level of loss of discrimination to pinprick was at T4. Hemodynamic and respiratory parameters were recorded continuously at 5 -min intervals during the procedure. The patient received supplemental oxygen at $2 \mathrm{~L} / \mathrm{min}$ by nasal cannula, and the oxygen saturation remained at $98 \%$ until the end of surgery. Hypotension and bradycardia were not observed during the operation. After the operation, the patient was observed in the post-anesthetic unit for complete regression of the block. The duration of the sensory block was $125 \mathrm{~min}$ and the duration of motor block was $95 \mathrm{~min}$. The patient was discharged from the hospital on the $2^{\text {nd }}$ day postpartum. On the $25^{\text {th }}$ day postpartum, the patient felt numbness and weakness at the lower extremities. On neurological assessment, muscle strength of the gastrocnemius and quadriceps bilaterally were $2 / 5(+)$ and $3 / 5(+)$, respectively. Muscle strength on bilateral foot dorsiflexion and plantar flexion was 2/5 (+). The patient was unable to walk on toes and walked on heels, and the lower extremities were hypoesthetic. The patellar and Achilles tendon reflexes were bilaterally negative. No pathological findings were detected on lumbosacral magnetic resonance imaging (MRI). Electromyography revealed a mixed type of polyneuropathy, where recordings compatible with partial bilateral peroneal (with total left peroneal nerve palsy), tibial and mild degree bilateral femoral lesion were observed. The patient was considered as neurotoxicity due to spinal ropivacaine. The patient was referred to the physical therapy and rehabilitation clinic. The symptoms relieved partially at the end of the $2^{\text {nd }}$ month and regressed completely at the end of the $3^{\text {rd }}$ month.

\section{Discussion}

Postpartum neurological complications following regional anesthesia occur very rare and may cause significant morbidity in previously healthy young women. ${ }^{[2]}$ The incidence of neurological injury associated with pregnancy and delivery is approximately $1 \% \cdot{ }^{[7]} \mathrm{Neu}-$ rological complications directly attributable to obstetric regional anesthesia are rare and the incidence of permanent harm is between 1:80.000 and 1:320.000. ${ }^{[8]}$ Nerve injury accounts for the majority of litigation against obstetric anesthetists, most commonly temporary radiculopathy of a lumbar or sacral root. ${ }^{[9]}$

Obstetric risk factors include nulliparity, the lithotomy position, and prolonged second stage of labor. [7] Regional anesthesia techniques may contribute indirectly such as longer second stage of labor, failure to appreciate symptoms of impending nerve injury. Obstetric palsy may be reduced by allowing a period of passive fetal descent, changing positions frequently during active pushing, and minimizing motor and dense sensory blockade through the use of dilute epidural local anesthetics. ${ }^{[6]}$

Nerve compression due to maternal positioning, the descending fetal head, or instrumental delivery results in a unilateral (occasionally bilateral) sensory and motor deficit. Common obstetric palsies include lateral cutaneus nerve, femoral nerve, obturatory nerve, lumbosacral plexus, and common peroneal nerve and L5 or S1 spinal root. ${ }^{[6]}$

The incidence of neurologic sequelae following the application of local anesthetics is still to be determined. Experimental studies suggested that levobupivacaine and ropivacaine in high concentrations may produce damage on neuronal structures, but 
clinical experience proves that their application is very well tolerated with regard to neurotoxicity. ${ }^{[10-12]}$

In view of the reduced toxic potential, ropivacaine has a definite edge over bupivacaine in regional anesthetic techniques requiring large volumes of local anesthetic. However, this drug has also been extensively studied over the past many years for its intrathecal use. When identical doses of isobaric ropivacaine and bupivacaine were compared, ropivacaine was found to have almost similar efficacy but shorter duration of sensory and motor block. ${ }^{[13]}$

Local anesthetics affect the spinal cord vessels when administered into the spinal or epidural space. The effects on spinal cord blood flow of drugs applied for spinal anesthesia are important, as neurotoxicity and disturbance in normal neurologic function may result from a decrease in spinal cord blood flow..$^{[14,15]}$ Bupivacaine has been shown to reduce spinal cord blood flow when applied to intrathecally ${ }^{[16-18]}$ and recently, ropivacaine was shown to have the same properties. ${ }^{[18]}$ The clinical relevance of this vasoconstrictory effect in the spinal cord is related to the degree of reduction in blood flow. Severe vasoconstriction may result in ischaemic neuropathological injuries ${ }^{[15]}$ whereas moderate decreases of about $50 \%$ may affect normal cell function and nociceptive transmission. ${ }^{[14]}$ Kristensen et al., ${ }^{[19]}$ demonstrated that intrathecal ropivacaine in clinically relevant concentrations minimally altered the spinal cord blood flow in rats.

Direct trauma to the spinal cord or nerve roots may be caused by needles or catheters, or by intraneural injection, and is usually painful. ${ }^{[6]}$ The clinical consequence is a sensory and motor deficit in the distribution of the spinal nerve; full recovery within months is usua. ${ }^{[6]}$

Mechanical trauma (compression or stretch injuries) may also damage supporting vascular structures, compromising perineural blood flow and resulting in nerve ischemia. ${ }^{[6]}$

Direct nerve injury from spinal or epidural needles and catheters is extremely rare. Pressure on the cord or spinal roots with a needlepoint produces excruciating pain, and the needle would be withdrawn immediately. The spinal needle was easily placed in the first attempt and during the placement of the spinal needle and injection of local anesthetic drug, we did not observe pain, paresthesia, or bleeding. And there was no abnormal finding in the MRI scan of our case.

It was reported that in a patient who had epidural ropivacaine for postoperative analgesia occurred sudden sensory loss and flaccid paralysis of bilateral lower extremities on the $2^{\text {nd }}$ day after cesarean section. MRI and myelogram showed no abnormality of the spinal cord. Her neurological deficit showed slight improvement but her sensory and motor paralysis still remained. Neurotoxicity of ropivacaine may be the cause of this neurological deficit. ${ }^{[20]}$ The symptoms of our case relieved partially at the end of the $2^{\text {nd }}$ month and regressed completely at the end of the $3^{\text {rd }}$ month.

Al-Nasser, ${ }^{[21]}$ reported the toxic effects of epidural analgesia with ropivacaine in a diabetic patient. The potential neurotoxicity of local anesthetics may cause transient or permanent nerve injury after regional anesthesia/analgesia techniques in diabetic patients, probably by additional ischemic insult and intraneural edema. ${ }^{[22]}$ Patients with pre-existing generalized neuropathy (diabetes mellitus, chemotherapy, multiple sclerosis, radiculopathy, or polio) may represent a population at a higher risk of local anesthetic toxicity. In these patients, the compressed or severely injured neurons at one site or mildly injured at several sites may be susceptible to damage at a more distal location. ${ }^{[23]}$ Our case had no additional disease such as diabetes mellitus, anemia, chemotherapy, multiple sclerosis, neuromusculary disease, radiculopathy, or discopaty before.

On the other hand, there are many additional factors contributing to the clinical manifestations of local anesthetic toxicity such as exposure time, catheter use and perhaps obesity, ${ }^{[24]}$ heavy smoking, and alcholic polyneuropathy as a result of direct neurotoxicity by ethanol and/or nutritional deficiency. ${ }^{[25]}$ Our patient had no history of smoking, and we used single-shot spinal anesthesia technique instead of the catheter technique.

Hypotension is the most common complication of regional anesthesia and severe hypotension is associated with ischemia in spinal cord blood flow. ${ }^{[6]}$ In our case, no severe hypotension was observed during regional anesthesia. 


\section{Conclusion}

Consequently; to the prevention of irreversible postpartum permanent neurologic deficits, the diagnosis should be made using a detalied neurologic examination along with MRI or CT. Referral to neurologist or physiotherapists may be necessary for treatment and follow-up of the patient.

\section{Conflict-of-interest issues regarding the authorship or article: None declared.}

\section{Peer-rewiew: Externally peer-reviewed.}

\section{References}

1. Chambers DJ, Bhatia K. Cranial nevre palsy following central neuraxial block in obstetrics-a review of the literature and analysis of 43 case reports. Int J Obstet Anesth 2017;31:13-26. [CrossRef]

2. Jadon A. Complications of regional and general anaesthesia in obstetric practice. Indian J Anaesth 2010;54(5):41520. [CrossRef]

3. Sanli S, Yegin A, Kayacan N, Yilmaz M, Coskunfirat N, Karsli B. Effects of hyperbaric spinal ropivacaine for caesarean section: With or without fentanyl. Eur J Anaesthesiol 2005;22(6):457-61. CrossRef]

4. Liu Q, Wang JJ, Yan HY, Wang YQ, Qin CW, Li ML. Safety and pharmacodynamic mechanism of ropivacaine lumbar anesthesia in Cesarean section. J Biol Regul Homeost Agents 2017;31(1):71-6.

5. Al-Abdulhadi O, Beihl D, Ong B, Boker A. Hyperbaric spinal for elective Cesarean section-ropivacaine vs bupivacaine. Middle East J Anaesthesiol 2007;19(2):385-97.

6. Chamber DJ, Howells Allison CL. Neurological complications in obstetric regional anaesthesia. Anaesth Intensive Care Med 2016;17(8):372-4. [CrossRef]

7. Wong C. Neurologic deficits and labor analgesia. Reg Anesth Pain Med 2004;29(4):341-51. [CrossRef]

8. Cook TM, Counsell D, Wildsmith JA. Major complications of central neuraxial block: Report on the Third National Audit Project of the Royal College of Anaesthetists. Br J Anaesth 2009;102(2):179-90. [CrossRef]

9. Davies JM, Posner KL, Lee LA, Cheney FW, Domino KB. Liability associated with obstetric anesthesia: A closed claims analysis. Anesthesiology 2009;110(1):131-9. [CrossRef]

10. Yamashita $A$, Matsumoto $M$, Matsumoto $S$, Itoh $M$, Kawai $K$, Sakabe T. A comparison of the neurotoxic effects on the spinal cord of tetracaine, lidocaine, bupivacaine, and ropivacaine administered intrathecally in rabbits. Anesth Analg 2003;97(2):512-9. [CrossRef]

11. lohom G1, Lan GB, Diarra DP, Grignon Y, Kinirons BP, Girard
F, et al. Long-term evaluation of motor function following intraneural injection of ropivacaine using walking track analysis in rats. Br J Anaesth 2005;94(4):524-9. [CrossRef]

12. Muguruma T, Sakura S, Kirihara Y, Saito Y. Comparative somatic and visceral antinociception and neurotoxicity of intrathecal bupivacaine, levobupivacaine, and dextrobupivacaine in rats. Anesthesiology 2006;104(6):1249-56. [CrossRef]

13. McNamee DA, McClelland AM, Scott S, Milligan KR, Westman L, Gustafsson U. Spinal anaesthesia: Comparison of plain ropivacaine $5 \mathrm{mg} \mathrm{ml}(-1)$ with bupivacaine $5 \mathrm{mg} \mathrm{ml}$ for major orthopaedic surgery. Br J Anaesth 2002;89(5):702-6.

14. Barber A, Wild A, Wedel R. Do local vasomotor effects elicit the motor deficits induced by intrathecally applied substance $P$ antagonists in the rat? Neurosci Lett 1987;80(2):219-23.[CrossRef]

15. Freedman J, Post C, Kåhrström J, Ohlen A, Mollenholt P, Owman $C$, et al. Vasoconstrictor effects in spinal cord of the substance $P$ antagonist [D-Arg, D-Trp7,9 Leu11]-substance $\mathrm{P}$ (Spantide) and somatostatin and interaction with thyrotropin releasing hormone. Neuroscience 988;27(1):267-78.

16. Kozody R, Ong B, Palahniuk RJ, Wade JG, Cumming MO, Pucci WR. Subarachnoid bupivacaine decreases spinal cord blood flow in dogs. Can Anaesth Soc J 985;32(3):216-22.

17. Crosby G. Local spinal cord blood flow and glucose utilization during spinal anesthesia with bupivacaine in conscious rats. Anesthesiology 1985;63(1):55-60 [CrossRef]

18. Kristensen JD, Karlsten R, Gordh T. Spinal cord blood flow after intrathecal injection of ropivacaine: A screening for neurotoxic effects. Anesth Analg 1996;82(3):636-40 [CrossRef]

19. Kristensen JD, Karlsten R, Gordh T. Spinal cord blood flow after intrathecal injection of ropivacaine and bupivacaine with or without epinephrine in rats. Acta Anaesthesiol Scand 1998;42(6):685-90. [CrossRef]

20. Ikeya K. Neurological deficit following lumbar epidural anesthesia with ropivacaine. Masui 2007;56(8):945-8.

21. Al-Nasser B. Toxic effects of epidural analgesia with ropivacaine $0.2 \%$ in diabetic patient. J Clin Anesth 2004;16(3):220-3. [CrossRef]

22. Kanai Y, Katsuki H, Takasaki M. Lidocaine disruptss neuronal membrane of rat sciatic nerve in vitro. Anesth Analg 2000;91(4):944-8 [CrossRef]

23. Hebl Jr., Horlocker TT, Sorenson EJ, Schroeder DR. Regional anesthesia does not increase the risk of postoperative neuropathy in patients undergoing ulnar nerve transposition. Anesth Analg 2001;93(6):1606-11

24. Radwan IA, Saito S, Goto F. The neurotoxicity of local anesthetics on growing neurons: A comparative study of lidocaine, bupivacaine, mepivacaine, and ropivacaine. Anesth Analg 2002;94(2):319-24. [CrossRef]

25. Ready LB, Plumer MH, Haschke RH, Austin E, Sumi SM. Neurotoxicity of intrathecal local anesthetics in rabbits. Anesthesiology 1985;63(4):364-70 [CrossRef] 